\title{
Effect of the claw disorders on production performance in dairy cattle
}

\author{
Vlček, Michal-Kasarda, Radovan \\ Slovak University of Agriculture in Nitra, Faculty of Agrobiology and Food Resources, \\ Department of Genetics and Animal Breeding Biology, Nitra, Slovak Republic \\ xvlcekm@uniag.sk
}

SUMMARY

\begin{abstract}
The aim of the study was the influence of claw disorders on production traits in dairy cattle. Observed were claw traits as claw angle, claw length, heel index, claw height, claw diagonal and claw width. Right hind claw after functional trimming was evaluated. Occurrence of claw disorders like interdigital dermatitis and heel erosion (IDHE), digital dermatitis (DD) and sole ulcer (SV) as well as the progress of disease were observed. Basic summary and variation statistics was performed by the SAS software. Two herds were included in the study. Holstein dairy cows ( $\mathrm{n}=101)$ produced $11875 \mathrm{~kg}$ of milk, $468 \mathrm{~kg}(3.94 \%)$ offat and $396 \mathrm{~kg}(3.34 \%)$ of proteins. Holstein cows were affected with IDHE in 22 cases, with DD in 6 cases and with sole ulcer in 10 cases. Slovak Simmental dairy cows ( $\mathrm{n}=101)$ produced $5834 \mathrm{~kg}$ of milk, $258 \mathrm{~kg}$ $(4.44 \%)$ of fat and $209 \mathrm{~kg}(3.59 \%)$ of proteins. Slovak Simmental cows were affected with IDHE in 8 cases, with DD in 5 cases and with sole ulcer in 19 cases. Observed was that claw disorders caused deviations of milk production.
\end{abstract}

Keywords: Holstein, Slovak Simmental, claw, IDHE, DD, sole ulcer

\section{INTRODUCTION}

Foot disorders are the main cause of dairy cow lameness and are considered to have a major impact on the welfare of dairy cattle (Bruijnis et al. 2012). Impaired mobility from a claw disorder or, more rarely, a leg disorder is associated, both directly and indirectly, with considerable costs. The direct costs are related to treatment of the disorder. Indirect costs include loss of milk production, impaired fertility, and premature involuntary culling (Laursen et al. 2009). Foot disorders forego another problems. Because of pain, lame animals with clinical sights often lie and decreased time spent at feeding and drinking. They don't have enough nutrients necessary for maintenance and for production and reproduction (Kasarda et al. 2015).

Krupa et al. (2015) found out that the relative economic weight of claw disorders is $0.22 \%$.

Sole hemorrhage is the early clinical sign of sole ulcer but not only becomes visible several weeks or months after the initial injury. Affected animals may show different degrees of lameness and may have an obvious cow-hocked stance in an effort to place more weight on the medial claws. Early cases of sole ulcer are characterized by hemorrhage and pain at the sole ulcer site without an open horn defect. With mature lesions, the surface of the horn appears damaged and is often loose and underrun around the ulcer site (van Amstel and Shearer 2006a).

The main sign of digital dermatitis is extremely severe lameness in one or more limbs. Affected animals are extremly reluctant to bear weight on an affected limb. Such animals are prone to recumbence and often also show a precipitous drop in milk production. The disease is highly contagious and outbreaks are common (Haskell 2008).

Subacute interdigital dermatitis is characterized by epidermal thickening and can be seen in the dorsal and plantar/palmar interdigital clefts. In many cases the infection extends to the heel horn, resulting in heel erosion, which at first has a pitted appearance, but later develops fissures with underrunning of heel horn. Heel erosion, which develops during this stage, predisposes to overgrowth of the heel caused by inflammation and increased blood flow to the perioplic corium. Overgrowth at the heel can result in sole ulcer formation. In addition to overgrowth, underrunning of the heel horn may result in trauma of the perioplic and even solar corium (van Amstel and Shearer 2006b).

\section{MATERIAL AND METHODS}

Two farms were considered for the study. Holstein and Slovak Simmental cows were analysed. Observed were claw traits as claw angle, claw length, heel index, claw height, claw diagonal and claw width (Figure 1-2). Right hind claw after functional trimming was evaluated. Occurrence of claw disorders like interdigital dermatitis and heel erosion, digital dermatitis and sole ulcer as well as the progress of disease were observed according to the methodology described by Vermunt and Greenough (1995) and Döpfer (1994).

Vermunt and Greenough (1995) described interdigital dermatitis and heel erosion:

0 - heel horn intact;

1 - slight defect of the horn integrity, pits or small fissures;

2 - v-shaped fissures or circular craters, extending small area of the heel;

3 - v-shaped fissures or circular craters, extending entire heel;

4 - profound fissures or craters, extending to the corium of the heel.

Döpfer (1994) classified digital dermatitis to 5 classes (M1 to M5):

M1 - early stage with a circumscribed granulomatous area (lesion 0.5 to $2 \mathrm{~cm}$ in diameter);

M2 - classical ulceration (lesion $>2 \mathrm{~cm}$ in diameter);

M3 - healing lesion covered by a scab after therapy;

M4 - skin alterations due to former M1 or M2 lesion;

M5 - no lesion or skin abnormalities.

Separately was evaluated appearance of sole ulcer. 


\section{Figure 1: Claw}
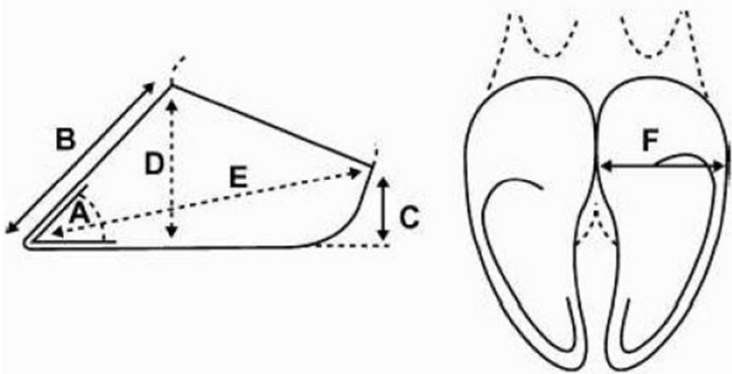

Note: A-claw angle, B- claw length, C- heel index, D- claw height, Eclaw diagonal, F- claw width, Source: Vermunt and Greenough (1995)

Figure 2: Measurement of claw width

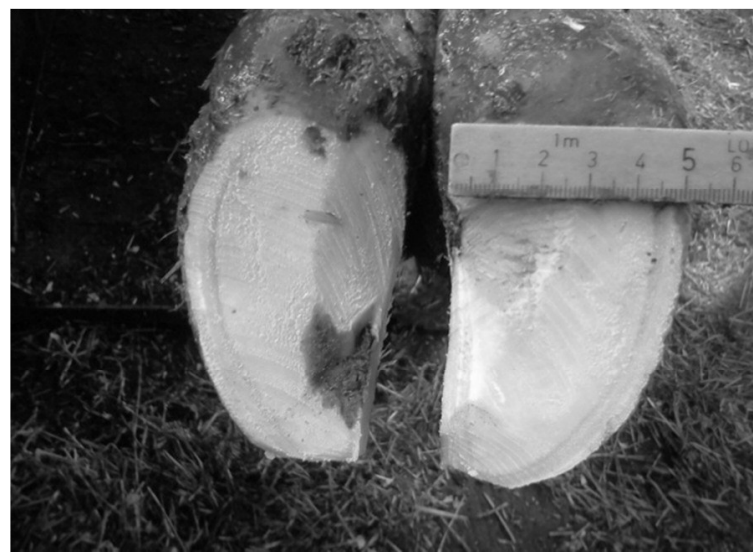

Source: Vlček (2012)

On each farm, cows were divided to groups according the number of lactation. Separately group of first lactations cows was evaluated. Second group consisted of cows on the second and higher lactations. In each group basic summary and variation statistics was performed. Production traits included milk production $(\mathrm{kg})$, fat production $(\mathrm{kg})$, fat content $(\%)$, protein production $(\mathrm{kg})$ and protein content (\%). Results were obtained separately for each group by the SAS software. Influence of claw disorders on production traits were studied.The significance of differences across production traits between both healthy and ill dairy cows were analysed using t-test.

\section{RESULTS AND DISCUSSION}

In Table 1 are the production traits of the Holstein and the Slovak Simmental herd separated by the stage of lactation. Selected herds belong to the population's nucleus and their production level is over the Slovak population average according to the results of the official milk recording system in Slovakia (The Breeding Services of the Slovak Republic, S. E. 2015).

In group of first lactation Holstein cows were observed differences between healthy and ill cows. Cows affected with disorders produced more fat and protein. Cows with IDHE produced $4 \mathrm{~kg}$ of fat more but $4 \mathrm{~kg}$ of protein and $209 \mathrm{~kg}$ of milk less than healthy. Cows with DD produced $9 \mathrm{~kg}$ of fat and $28 \mathrm{~kg}$ of protein more than healthy. Cows with sole ulcer produced $63 \mathrm{~kg}$ of fat and $42 \mathrm{~kg}$ of protein more than healthy. Cows with DD resp. sole ulcer produced $1069 \mathrm{~kg}$ resp. $1708 \mathrm{~kg}$ of milk more than healthy cows. Differences between healthy and ill cows were not significant (Table 2).

In group of first lactation Slovak Simmental cows were observed differences between healthy cows and cows with sole ulcer. Ill cows produced $845 \mathrm{~kg}$ of milk, $18 \mathrm{~kg}$ of fat and $19 \mathrm{~kg}$ of protein more than healthy. In group were 2 cows affected with DD and 1 with IDHE, so it was not possible to make relevant results (Table 3).

In group of second and higher lactation Holstein cows were observed differences between healthy and ill cows. Healthy cows produced $451 \mathrm{~kg}$ of milk, $18 \mathrm{~kg}$ of fat and $16 \mathrm{~kg}$ of protein more than cows with IDHE. Healthy cows produced $684 \mathrm{~kg}$ of milk, $43 \mathrm{~kg}$ of fat and $16 \mathrm{~kg}$ of protein more than cows with sole ulcer. In group was just 1 cow affected with DD, so it was not possible to make relevant results. Differences between healthy and ill cows were not significant (Table 4).

In group of second and later lactation Slovak Simmental cows (Table 5) differences between healthy and ill cows were observed. Healthy cows produced $1032 \mathrm{~kg}$ of milk, $50 \mathrm{~kg}$ of fat $(\mathrm{P}<0.01)$ and $35 \mathrm{~kg}$ of protein more than cows affected by IDHE.

Table 1.

Production traits of the Holstein and the Slovak Simmental herd

\begin{tabular}{|c|c|c|c|c|}
\hline & \multicolumn{2}{|c|}{ First lactations } & \multicolumn{2}{|c|}{ Second and higher lactations } \\
\hline & Mean & Std Dev & Mean & Std Dev \\
\hline & \multicolumn{4}{|c|}{ Holstein } \\
\hline Milk (kg) & 11146.13 & 2889.92 & 13082.79 & 2122.59 \\
\hline Fat (kg) & 438.87 & 128.35 & 515.00 & 102.08 \\
\hline Fat $(\%)$ & 3.94 & 0.39 & 3.94 & 0.45 \\
\hline Protein $(\mathrm{kg})$ & 374.89 & 99.26 & 430.68 & 74.04 \\
\hline \multirow[t]{2}{*}{ Protein $(\%)$} & 3.36 & 0.19 & 3.29 & 0.17 \\
\hline & \multicolumn{4}{|c|}{ Slovak Simmental } \\
\hline Milk (kg) & 5466.39 & 1378.26 & 6012.76 & 1710.07 \\
\hline Fat (kg) & 241.12 & 58.11 & 266.21 & 76.08 \\
\hline Fat $(\%)$ & 4.44 & 0.33 & 4.43 & 0.36 \\
\hline Protein $(\mathrm{kg})$ & 196.48 & 49.10 & 214.72 & 60.80 \\
\hline Protein $(\%)$ & 3.61 & 0.24 & 3.58 & 0.20 \\
\hline
\end{tabular}

Note: Std Dev=Standard deviation 
Holstein cows on the first lactations

\begin{tabular}{|c|c|c|c|c|c|c|c|}
\hline & & \multicolumn{2}{|c|}{ Healthy cows } & \multicolumn{2}{|c|}{ Ill cows } & \multirow{2}{*}{ Difference } & \multirow{2}{*}{ t-test } \\
\hline & & $\mathrm{N}$ & Mean & $\mathrm{N}$ & Mean & & \\
\hline \multirow{5}{*}{ IDHE } & Milk (kg) & 51 & 11186.00 & 12 & 10976.80 & 209.20 & $>0.05$ \\
\hline & Fat (kg) & 51 & 438.10 & 12 & 442.00 & -3.90 & $>0.05$ \\
\hline & Fat $(\%)$ & 51 & 3.91 & 12 & 4.03 & -0.12 & $>0.05$ \\
\hline & Protein $(\mathrm{kg})$ & 51 & 375.70 & 12 & 371.30 & 4.40 & $>0.05$ \\
\hline & Protein $(\%)$ & 51 & 3.36 & 12 & 3.37 & -0.01 & $>0.05$ \\
\hline \multirow{5}{*}{ DD } & Milk (kg) & 58 & 11061.30 & 5 & 12130.20 & -1068.90 & $>0.05$ \\
\hline & Fat (kg) & 58 & 438.20 & 5 & 446.80 & -8.60 & $>0.05$ \\
\hline & Fat $(\%)$ & 58 & 3.96 & 5 & 3.69 & 0.27 & $>0.05$ \\
\hline & Protein $(\mathrm{kg})$ & 58 & 372.60 & 5 & 401.00 & -28.40 & $>0.05$ \\
\hline & Protein $(\%)$ & 58 & 3.37 & 5 & 3.33 & 0.04 & $>0.05$ \\
\hline \multirow{5}{*}{ SU } & Milk (kg) & 60 & 11064.80 & 3 & 12772.30 & -1707.50 & $>0.05$ \\
\hline & Fat (kg) & 60 & 435.90 & 3 & 499.00 & -63.10 & $>0.05$ \\
\hline & Fat $(\%)$ & 60 & 3.94 & 3 & 3.94 & 0.00 & $>0.05$ \\
\hline & Protein $(\mathrm{kg})$ & 60 & 372.90 & 3 & 414.70 & -41.80 & $>0.05$ \\
\hline & Protein $(\%)$ & 60 & 3.37 & 3 & 3.23 & 0.14 & $>0.05$ \\
\hline
\end{tabular}

Note: $\mathrm{N}=$ Number of observations, IDHE=Interdigital dermatitis and heel erosion, $\mathrm{DD}=$ digital dermatitis, $\mathrm{SU}=$ sole ulcer

Table 3.

Slovak Simmental cows on the first lactations

\begin{tabular}{|c|c|c|c|c|c|c|c|}
\hline & & \multicolumn{2}{|c|}{ Healthy cows } & \multicolumn{2}{|c|}{ Ill cows } & \multirow{2}{*}{ Difference } & \multirow{2}{*}{ t-test } \\
\hline & & $\mathrm{N}$ & Mean & $\mathrm{N}$ & Mean & & \\
\hline \multirow{5}{*}{ IDHE } & Milk (kg) & 32 & 5427.30 & 1 & 6717.00 & -1289.70 & $>0.05$ \\
\hline & Fat (kg) & 32 & 239.10 & 1 & 306.00 & -66.90 & $>0.05$ \\
\hline & Fat $(\%)$ & 32 & 4.44 & 1 & 4.56 & -0.12 & $>0.05$ \\
\hline & Protein (kg) & 32 & 194.90 & 1 & 248.00 & -53.10 & $>0.05$ \\
\hline & Protein $(\%)$ & 32 & 3.61 & 1 & 3.69 & -0.08 & $>0.05$ \\
\hline \multirow{5}{*}{ DD } & Milk (kg) & 31 & 5392.60 & 2 & 6610.00 & -1217.40 & $<0.01$ \\
\hline & Fat (kg) & 31 & 238.20 & 2 & 287.00 & -48.80 & $>0.05$ \\
\hline & Fat $(\%)$ & 31 & 4.45 & 2 & 4.35 & 0.10 & $>0.05$ \\
\hline & Protein $(\mathrm{kg})$ & 31 & 194.00 & 2 & 235.00 & -41.00 & $>0.05$ \\
\hline & Protein $(\%)$ & 31 & 3.62 & 2 & 3.55 & 0.07 & $>0.05$ \\
\hline \multirow{5}{*}{ SU } & Milk (kg) & 28 & 5338.40 & 5 & 6183.20 & -844.80 & $>0.05$ \\
\hline & Fat $(\mathrm{kg})$ & 28 & 238.40 & 5 & 256.60 & -18.20 & $>0.05$ \\
\hline & Fat $(\%)$ & 28 & 4.49 & 5 & 4.16 & 0.33 & $<0.05$ \\
\hline & Protein $(k g)$ & 28 & 193.60 & 5 & 212.60 & -19.00 & $>0.05$ \\
\hline & Protein $(\%)$ & 28 & 3.64 & 5 & 3.43 & 0.21 & $>0.05$ \\
\hline
\end{tabular}

Note: $\mathrm{N}=$ Number of observations, IDHE=Interdigital dermatitis and heel erosion, $\mathrm{DD}=$ digital dermatitis, $\mathrm{SU}=$ sole ulcer

Healthy cows produced $46 \mathrm{~kg}$ of milk, $3 \mathrm{~kg}$ of fat and $2 \mathrm{~kg}$ of protein more than cows affected with DD. Healthy cows produced $995 \mathrm{~kg}$ of milk $(\mathrm{P}<0.05), 55 \mathrm{~kg}$ of fat $(\mathrm{P}<0.01), 0.17 \%$ of fat, $44 \mathrm{~kg}$ of protein $(\mathrm{P}<0.01)$ and $0.16 \%$ of protein $(\mathrm{P}<0.05)$ more than cows with sole ulcer (Table 5).

Digital dermatitis has been associated with decreased milk yield, reduced reproductive performance, increased involuntary culling rate and reduced general well-being of the animals (Onyiro et al. 2008). The most frequent cause of lameness, claw diseases as sole ulcer, white line disease, interdigital necrobacillosis and digital dermatitis, were in association with reduced milk yield (Green et al. 2002). Pavlenko et al. (2011) concluded that cows affected with digital dermatitis and sole ulcer produced less milk compared with healthy cows.

In Holstein population $48 \%$ of cows were affected by claw defects in Slovakia. Proportion of digital dermatitis, interdigital dermatitis and heel erosion and sole ulcers was almost at the same level, in $16 \%$ of observations. In population of Slovak Simmental breed were claw defects observed in 37\%. High proportion of sole ulcers, observed in $21 \%$, was interesting (Kasarda et al. 2015). 
Holstein cows on the second and later lactations

\begin{tabular}{|c|c|c|c|c|c|c|c|}
\hline & & \multicolumn{2}{|c|}{ Healthy cows } & \multicolumn{2}{|c|}{ Ill cows } & \multirow{2}{*}{ Difference } & \multirow{2}{*}{ t-test } \\
\hline & & $\mathrm{N}$ & Mean & $\mathrm{N}$ & Mean & & \\
\hline \multirow{5}{*}{ IDHE } & Milk (kg) & 28 & 13201.60 & 10 & 12750.20 & 451.40 & $>0.05$ \\
\hline & Fat $(\mathrm{kg})$ & 28 & 519.60 & 10 & 502.10 & 17.50 & $>0.05$ \\
\hline & Fat $(\%)$ & 28 & 3.94 & 10 & 3.94 & 0.00 & $>0.05$ \\
\hline & Protein (kg) & 28 & 434.90 & 10 & 418.80 & 16.10 & $>0.05$ \\
\hline & Protein $(\%)$ & 28 & 3.30 & 10 & 3.28 & 0.02 & $>0.05$ \\
\hline \multirow{5}{*}{ DD } & Milk (kg) & 37 & 13044.50 & 1 & 14500.00 & -1455.50 & $>0.05$ \\
\hline & Fat $(\mathrm{kg})$ & 37 & 510.90 & 1 & 668.00 & -157.10 & $>0.05$ \\
\hline & Fat $(\%)$ & 37 & 3.92 & 1 & 4.61 & -0.69 & $>0.05$ \\
\hline & Protein (kg) & 37 & 429.20 & 1 & 486.00 & -56.80 & $>0.05$ \\
\hline & Protein $(\%)$ & 37 & 3.29 & 1 & 3.35 & -0.06 & $>0.05$ \\
\hline \multirow{5}{*}{ SU } & Milk (kg) & 31 & 13208.70 & 7 & 12525.10 & 683.60 & $>0.05$ \\
\hline & Fat (kg) & 31 & 522.80 & 7 & 480.30 & 42.50 & $>0.05$ \\
\hline & Fat $(\%)$ & 31 & 3.96 & 7 & 3.82 & 0.14 & $>0.05$ \\
\hline & Protein (kg) & 31 & 433.60 & 7 & 417.60 & 16.00 & $>0.05$ \\
\hline & Protein $(\%)$ & 31 & 3.29 & 7 & 3.32 & -0.03 & $>0.05$ \\
\hline
\end{tabular}

Note: $\mathrm{N}=$ Number of observations, IDHE=Interdigital dermatitis and heel erosion, $\mathrm{DD}=$ digital dermatitis, $\mathrm{SU}=$ sole ulcer

Table 5 .

Slovak Simmental cows on the second and later lactations

\begin{tabular}{|c|c|c|c|c|c|c|c|}
\hline & & \multicolumn{2}{|c|}{ Healthy cows } & \multicolumn{2}{|c|}{ Ill cows } & \multirow{2}{*}{ Difference } & \multirow{2}{*}{ t-test } \\
\hline & & $\mathrm{N}$ & Mean & $\mathrm{N}$ & Mean & & \\
\hline \multirow{5}{*}{ IDHE } & Milk (kg) & 61 & 6119.00 & 7 & 5086.70 & 1032.30 & $>0.05$ \\
\hline & Fat (kg) & 61 & 271.40 & 7 & 221.00 & 50.40 & $<0.01$ \\
\hline & Fat $(\%)$ & 61 & 4.44 & 7 & 4.34 & 0.10 & $>0.05$ \\
\hline & Protein (kg) & 61 & 218.30 & 7 & 183.30 & 35,00 & $>0.05$ \\
\hline & Protein $(\%)$ & 61 & 3.58 & 7 & 3.61 & -0.03 & $>0.05$ \\
\hline \multirow{5}{*}{ DD } & Milk (kg) & 65 & 6014.80 & 3 & 5969.30 & 45.50 & $>0.05$ \\
\hline & Fat (kg) & 65 & 266.30 & 3 & 263.70 & 2.60 & $>0.05$ \\
\hline & Fat $(\%)$ & 65 & 4.43 & 3 & 4.42 & 0.01 & $>0.05$ \\
\hline & Protein (kg) & 65 & 214.80 & 3 & 213.30 & 1.50 & $>0.05$ \\
\hline & Protein $(\%)$ & 65 & 3.58 & 3 & 3.58 & 0,00 & $>0.05$ \\
\hline \multirow{5}{*}{ SU } & Milk (kg) & 54 & 6217.60 & 14 & 5222.80 & 994.80 & $<0.05$ \\
\hline & Fat $(\mathrm{kg})$ & 54 & 277.40 & 14 & 222.90 & 54.50 & $<0.01$ \\
\hline & Fat $(\%)$ & 54 & 4.47 & 14 & 4.30 & 0.17 & $>0.05$ \\
\hline & Protein (kg) & 54 & 223.80 & 14 & 179.60 & 44.20 & $<0.01$ \\
\hline & Protein $(\%)$ & 54 & 3.61 & 14 & 3.45 & 0.16 & $<0.05$ \\
\hline
\end{tabular}

Note: $\mathrm{N}=$ Number of observations, IDHE=Interdigital dermatitis and heel erosion, $\mathrm{DD}=$ digital dermatitis, $\mathrm{SU}=$ sole ulcer

\section{CONCLUSIONS}

Observed results in group of first lactation cows are in contrary to usually confirmed fact that production of ill cows is depressed. On the other hand high production cows are more often ill due to more concentrate nutrition and therefore metabolic disorder. Higher lactations of affected cows on the first lactations might be explained by their longer days open causing longer real lactations and therefore higher both real and official 305 days lactations.
Analysed herds belong to the top dairy herds of Holstein resp. Simmental cattle in Slovakia and this affected the results of analysis.

In contrary to results of first lactation cows, results clearly show that production of ill cows is depressed, which is in agreement with generally observed tendency. On the first lactation majority of cows is culled, average functional length of production life of cow in dairy herd is 2.3 lactations, first lactation cows are culled mainly due to loss of reproduction. Claw disorder is one of the 
top important factors of culling on second and later lactations. Further study on genetic background of claw formation and influence of claw disorders on reproduction and functional traits will be essential.

\section{ACKNOWLEDGEMENT}

This study was supported by the Slovak Research and Development Agency under the Contract No. APVV-14-0054.

\section{REFERENCES}

Bruijnis, M. R. N.-Beerda, B.-Hogeveen, H.-Stassen, E. N. (2012): Assessing the welfare impact of foot disorders in dairy cattle by a modelling approach. Animal. 6. 6: 962-970.

Döpfer, D. (1994): Epidemiological investigations about digital dermatitis on two dairy farms. Ph.D. Thesis. Tierärtzliche Hochschule. Hannover. Germany

Green, L. E.-Hedges, V. J.-Schukken, Y. H.-Blowey, R. W.Packington, A. J. (2002). The impact of clinical lameness on the milk yield of dairy cows. Journal of Dairy Science. 85. 9: 2250-2256.

Haskell, S. R. R. (2008): Digital (papillomatous) dermatitis Blackwell's five-minute veterinary consult: Ruminant. Iowa USA: 298.

Kasarda, R.-Vlček, M.-Ofúkaný, M.-Chudej, P. (2015): Detail view on claw disorders (in Slovak). Miniinfo apríl 2015. 16-19.

Krupa, E.-Krupová, Z.-Michaličková, M.-Kasarda, R.-Kadlečík, O (2015): Economic weight of characters in dual purpose cattle breed (in Czech). Náš chov. 75. 5: 31-34

Laursen, M. V.-Boelling, D.-Mark, T. (2009): Genetic parameters for claw and leg health, foot and leg conformation, and locomotion in Danish Holsteins. Journal of Dairy Science. 92. 4: 1770-1777.
Onyiro, O. M.-Andrews, L. J.-Brotherstone, S. (2008): Genetic Parameters for Digital Dermatitis and Correlations with Locomotion, Production, Fertility Traits, and Longevity in Holstein-Friesian Dairy Cows. Journal of Dairy Science. 91. 10: 4037-4046.

Pavlenko, A.-Bergsten, C.-Ekesbo, I.-Kaart, T.-Aland, A.-Lidfors, L. (2011): Influence of digital dermatitis and sole ulcer on dairy cow behaviour and milk production. Animal. 5. 8: 1259-1269.

SAS (2009): SAS/STAT® User's Guide Version 9.2 Cary: SAS Institute Inc.

The Breeding Services of the Slovak Republic, S. E. (2015): The results of dairy herd milk recording in Slovak Republic in control year 2014-2015. http://pssr.sk/org/publ/2015/hd/rocenka/ml_14_15/rocenka/Ro\%C4\%8Denka\%20Mlieko\%202015\%20web.pdf

van Amstel, S.-Shearer, J. (2006a): Corrective trimming of horn lesions. Manual for Treatment and Control of Lameness in Cattle. Iowa. USA: 74

van Amstel, S.-Shearer, J. (2006b): Interdigital dermatitis (heel erosion, slurry heel). Manual for Treatment and Control of Lameness in Cattle. Iowa. USA: 165

Vermunt, J. J.-Greenough, P. R. (1995): Structural characteristics of the bovine claw horn growth and wear, horn hardness and claw conformation. The British Veterinary Journal. 151: 157-180. 
